\title{
We're All in This Together: How one University Drew on Collective Impact Principles to Advance Student Success in Higher Education
}

\author{
Bruce Jones, Maureen Croft and Teri Longacre
}

\begin{abstract}
Student attrition rates in higher education are an ongoing concern in the U.S, and are costly to students themselves, colleges and universities, and the economy in terms of dollars and human potential. Thus, the need to identify solutions to student attrition is pressing for both students who are enrolled in institutions of higher education today, and for multiple generations of students yet to enroll. This article discusses collective impact as a model of intervention at an urban university and the quest to promote institutional efficacy around student retention and graduation strategies in partnership with internal (on-campus) and external (off-campus) constituents.
\end{abstract}

Key Words: Student attrition; student retention; student graduation; low socioeconomic status; Pell Grant eligible

\section{Interdependency of the Ecosystem}

"We're all in this together", Senator Bill Nelson (FL) affirmed as he soared into outer space at an estimated 18,000 miles per hour. In 1986, the U.S. Senator had the privilege to serve as a member of the astronaut crew on board the Challenger Space Shuttle. As he peered out the window of the space shuttle on its rapid ascent, his home state of Florida quickly faded into a view of the United States. Seconds later, the United States faded into a view of the planet. In his online bio, he writes "from that perspective, you can see how we're all in this together . . . if we could just remember that, we'd sure get a lot more done” (Nelson, 2016).

An ecosystem, such as planet earth, is about interdependence. Bronfenbrenner (1986), who is a pioneer in perspectives on ecosystemic approaches to understanding the dynamic between people and institutions, and Hightower-Weaver (2008), who subscribe to ecosystemic approaches to public policy making, discuss the value in recognition that components of an ecosystem are interdependent. A fully viable ecosystem is one whereby all parts of said system are in a harmonious state of success. In contrast, when one part of an ecosystem suffers, the entire system is adversely affected in some way. In this respect, think of the 1986 Ukrainian, Chernobyl nuclear plant disaster. Evidence of the disaster showed up in parts of Europe as the earth's winds carried the deadly nuclear cloud across the earth's atmosphere. Suddenly, what was initially characterized as a U.S.S.R. problem became problematic for European population centers. Consistent with the notion of the ecosystem, we know that human neglect and indifference in one part of the world can impact the livelihoods of individuals and communities thousands of miles away in other parts of the world. Because of this, many of the issues that we face require collective solutions, which require multiple constituencies to be involved in the development and implementation of solutions. 
Education, as an educational ecosystem, is no exception to this rule (Goodlad, 1984). The levels of efficacy of our educational systems impact the United States and the world. For example, in many of the nations' urban centers, our public schools are often metaphorically, and in practice referred to, as warehouses, armed camps, preparatory places for prison, or dropout factories (Castagno \& Brayboy, 2008; Garcia, Jensen \& Scribner, 2009; McKinsey \& Company, 2009; Ream \& Rumberger, 2008; Schott Foundation, 2008). In American higher education, student attrition rates are a major concern as students drop out at unacceptable rates. Such departures are costly to the students themselves, the colleges and universities, and the U.S. economy (Carnevale, Smith \& Strohl, 2010; Dodge, Mitchell \& Mensch, 2009). Furthermore, this exacerbates the shortage of skilled workers:

The Georgetown University Center on Education and the Workforce shows that by 2018, we will need 22 million new college degrees but will fall short of that number by at least 3 million postsecondary degrees, Associate’s or better. In addition, we will need at least 4.7 million new workers with postsecondary certificates. At a time when every job is precious, this shortfall will mean lost economic opportunity for millions of American workers (Carnevale, Smith \& Strohl, 2010, p. 3).

The failure to ensure that our education system succeeds results in tremendous social, economic and moral cost to our political economy (Arum \& LaFree, 2008; Coontz, 1992). The consequences of this failure manifest through the enormous loss of human potential. The children and students that we fail may have been the very children and students who could have made a life-altering discovery. These children and students could have been the next generation of university academics, scholars, key community leaders, and Nobel Prize recipients.

Furthermore, our lack of institutional efficacy in the education of economically poor children and students comes at tremendous cost to society's level of mental and physical safety in the form of crime, prison construction, gated communities, unemployment, welfare and unabated poverty generation after generation (Arum \& LaFree, 2008). Obtaining a college education is a vehicle to upward mobility (Baum, Ma \& Payea, 2013; Gupton \& Miksch, 2016). College-educated adults are more likely to be in a position to pass income and wealth (i.e., home ownership, investments, savings, or property) to a new generation of descendants. In this respect, our need to engage in collective problem-solving is not just about children and students who are with us today. This is also about the multiple generations of children yet to be born and students yet to enroll in our colleges and universities.

Lastly, we face a moral dilemma in the eyes of the world. It is difficult to face the world as a model of democratic ideals when housed in a political economy that is incapable of collective problem solving around the plight of children and adults who are in a perpetual cycle of intergenerational poverty. With specific regard to colleges and universities, what will be the role of university research, teaching and service as a means to address issues faced by low-income students and our communities? How will research, teaching and service interface and work effectively with institutions on and off-campus to ensure the success of all students, particularly low-income students? Lastly, what practical and conceptual guides will drive the work of comprehensive efforts to reduce attrition and increase retention and graduation rates of students 
on campus? These are key questions for the University of Houston, which is cited as the second most student diverse campus in the United States (US News and World Report, 2017).

\section{State and Local Context}

In response to facing low student progression to postsecondary education and disparities in degree attainment across demographic groups (National Center for Higher Education Management Systems, 2012), the state of Texas developed a higher education strategic plan aimed at increasing student success consistent with workforce needs and the goals of global competitiveness and economic prosperity for Texas (Texas Higher Education Coordinating Board, 2015). The strategic plan is ambitious in its goal: to increase certificate or degree attainment by citizens of Texas, and to generate marketable skills among postsecondary education college and university enrollees. In order to accomplish this, the strategic plan recognizes that success is contingent on the combined expertise and resources of a diverse set of stakeholders working collaboratively to achieve increased levels of student success.

As the fourth largest city in the U.S. and one of the most ethnically diverse, Houston plays a key role in this endeavor. The total population for the Houston metro area grew 26 percent from 2000-2010 with the African American population increasing by 26 percent and the total Hispanic population rising by 55 percent during the same time period. Additionally, 10 percent of the Houston population is college-age (18-24), with projections that by 2020, Hispanics will grow by 42.6 percent, and African-Americans will grow by 12.7 percent in this age group. It is critical that Houston's diverse and growing student population be prepared to succeed in today's global, high-tech, knowledge-based economy, which increasingly requires postsecondary education to ensure needed knowledge and skills (Carnevale, Smith \& Strohl, 2010). In Harris County, Texas, however, only 27.6 percent of the population 25 and older holds at least a college degree. Furthermore, Houston ranks $34^{\text {th }}$ among the 50 largest metropolitan areas in the U.S. for the percentage of the population aged 25 and older holding a college degree. There are also differences in attainment across groups with college degrees held by 66 percent of Asian immigrants, 39 percent of US-born Anglos, 20 percent of US-born Blacks, 17 percent of USborn Hispanics, and 8 percent of Hispanic immigrants (Kinder Institute, 2012).

\section{Texas and Poverty as a Factor}

In Texas an estimated 24.8 percent of all children live in poverty. This exceeds the national poverty rate, which stood at approximately 15 percent (Kinder Institute, 2012). In this regard, a large and growing number of postsecondary students face the challenges created by limited resources. Approximately one in three American undergraduates receive a Pell grant, and as a result, are considered a low-income (Chaplor, Cooper, Johnstone \& Karandieff, 2015). These demographic trends pose challenges to the economic growth of our state and region. However, rising postsecondary participation in Houston along with growing enrollment at Houston area community colleges and universities present a tremendous opportunity to significantly increase degree attainment through collaborative strategic efforts. This opportunity is enhanced by a longstanding tradition of the University of Houston of focusing on working-class citizens and a tradition of enrolling and serving low-income students. As it stands, forty-three percent of the undergraduate students attending the University receive Pell Grant assistance. 


\section{Student Success at the Heart of University Mission and Goals}

The University of Houston was founded in 1927 and today serves over 40,000 students with an estimated 300 undergraduate and graduate programs. The mission of the University of Houston is as follows: "to offer nationally competitive and internationally recognized opportunities for learning, discovery and engagement to a diverse population of students in a real-world setting” (University of Houston, 2017). The University Mission Statement recognizes three shared values. First, the University will meet the challenges of educating a dynamic mix of nontraditional and traditional students. Second, the University will promote excellence within the context of basic and applied research and scholarship. Finally, the University will identify and respond to the economic, social and cultural changes affecting the quality of life in the city of Houston, the state of Texas and in the world through its education, research and service.

At the University of Houston, and elsewhere in other institutions of higher education, student success is at the heart of its mission and goals. Students who face additional challenges that interfere with the ability to progress towards degree attainment need additional support and clear pathways for graduation. The identification and removal of institutional barriers and the provision of extra support are difficult challenges for institutions of higher education to overcome.

\section{Collective Impact: Using Ecosystemic Approaches to Solving Intractable Higher Education Challenges}

As indicated earlier, an ecosystem is, in part, about the relationships between individuals and institutions in a given community or social system and the interdependent nature of these relationships (Weaver-Hightower, 2008). In many ways we can examine the efficacy of an ecosystem through our understanding of these relationships, with respect to how individuals and institutions work to bring shared goals to fruition. The ecosystemic approach to problem solving, from a conceptual standpoint, allows us to understand the need to approach issues that concern student retention and graduation from a broad university and community-wide standpoint. Such a conceptual approach allows us (i.e., university professors, administrators, and staff, student representatives, key community constituents, community college, philanthropic and business sector representatives) to better understand the benefits of our interdependence, thus moving toward a more collective quest to become highly efficacious in the academic advancement of our students. This is particularly important given the resource shortages that we face coupled with the benefits of the intellectual capital that can arise from collaborative approaches to problem solving in the area of students and college completion.

It is one thing to believe in something and another matter to actually engage in action toward what one believes. In this respect, the ecosystemic approach serves as the conceptual-base for our work at the University of Houston while the basic tenets that are associated with collective impact serve as the practical-base for our work. These basic tenets provide the tools, guidelines and necessary steps for ensuring that we engage in the action that is necessary to actually promote, develop and implement a coordinated and shared community-wide responsibility for ensuring the success of our students. Figure 1 (below) illustrates the relationship between the conceptual underpinning, educational ecosystem, and the practical guide, collective impact (Kania \& Kramer, 2012), of our work. 


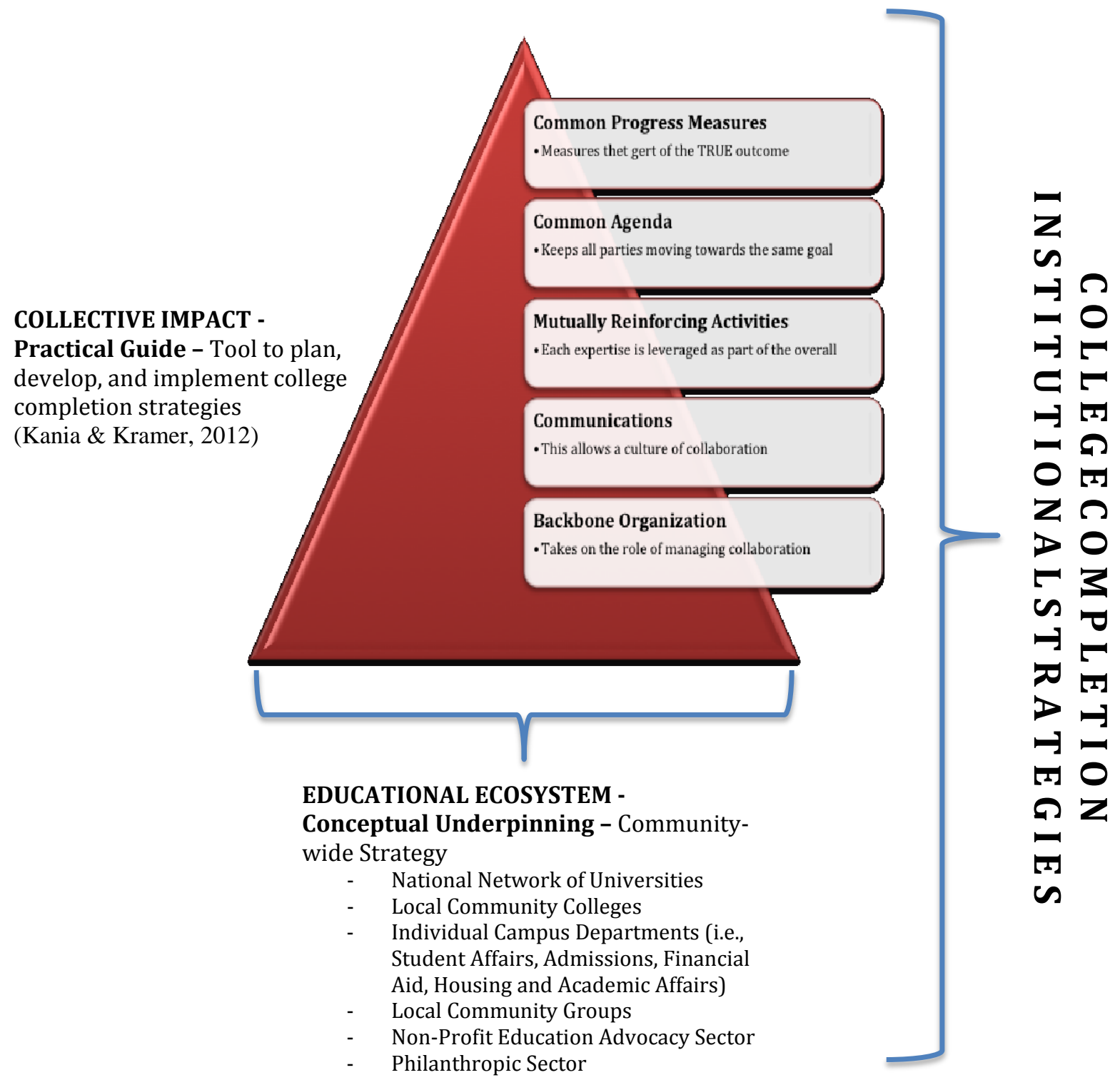

Figure 1. Collective Impact as a Means to Promote High Efficacy in Community-wide College Completion Efforts for Students

\section{Building a Tool Box of Interventions that Changes Higher Education Through the Use of Collective Impact}

The University of Houston shares the recognition put forth in the Texas Strategic Plan that statewide challenges require internal and external collaboration with the end goal of solving problems through incubation of ideas and the identification of scalable efficiencies (Texas Higher Education Coordinating Board, 2015). As such, the University has actively sought out collaborative initiatives aimed at improving not only the educational outcomes of our students but also of all low-income students impacted by our collective efforts with institutions invested in ensuring better postsecondary outcomes for low-income students. The University of Houston 
strives to bring multiple on-campus departments and off-campus agencies and institutions together to address issues that focus on low-income student retention, persistence and graduation. In this endeavor, we are guided by the recognition that we are an educational ecosystem-we are interdependent and must act accordingly, if we are to maximize our effectiveness on addressing these issues. From a conceptual and practical standpoint, the notion of collective impact begins with the recognition that no one individual and no one institution can address the multi-faceted issues that we face. In a climate of unstable resources and failure to make appreciable movement in closing attainment gaps among students, the University understands that collective efforts to advance cross-sector institutional efficacy, and the shared knowledge and efficiencies associated with collective problem-solving endeavors, are likely the only way to make appreciable social progress and to ensure the success of low-income students.

\section{Collective Impact in Action in Higher Education}

\section{Beyond Financial Aid}

Beyond Financial Aid is a national initiative that focuses on increasing the efficacy of institutions of higher education in the quest to retain and graduate low-income students. The initiative has been launched at a select number of universities with the principle support from the Lumina Foundation. Through this effort, a University-wide committee is working to identify barriers to achievement and possible areas for additional student support for low-income students. And, as a beta-test institution, $\mathrm{UH}$ is working to help the Lumina Foundation evaluate and refine the Beyond Financial Aid assessment tool.

\section{OASIS}

The Education Trust is a national, non-profit advocacy organization that promotes high academic achievement for all students, especially low-income and underrepresented minority students. Their initiative, Optimizing Academic Success and Institutional Strategy (OASIS), aims to create a network between eleven regional, comprehensive institutions that serve large populations of underrepresented minorities. The network aims to expand on the use of evidence-based practices at their campuses and to share their data and insights with each other in order to narrow the college completion gap between white and underrepresented minority students. Senior university leaders collaborate to analyze data and frequently communicate with each other in effort to develop best practices in student success. UH is an enthusiastic OASIS institutional partner.

\section{Completion Grant Project}

The Association of Public and Land-grant Universities (APLU) and the Coalition of Urban Serving Universities (USU) recently awarded the University of Houston $\$ 50,000$ to launch a pilot program to prevent low-income college students nearing graduation from dropping out. The University of Houston was one of nine institutions to receive a grant. The grants are for two years and are funded by Great Lakes Higher Education Guaranty Corporation and Lumina Foundation. Funds from the programs are used to strengthen the infrastructures in place to identify students close to graduation, who are at risk of dropping out due to inability to pay, and matching them with endowment funds in the form of Completion Grants. The grants are part of a 
broader success initiative known as Collaborating for Change, which matches institutions with peer mentors for assistance, professional development, and form learning communities to work through challenges, opportunities, and other unexpected developments. With guidance from APLU, USU, and peer mentors, institutions that received funding work toward the common goal of promoting timely completion through financial support. Collaboration and regular communication with mentors and other institutions has led to efficiencies in the grant award process at UH which are intended to increase the number of grants awarded to students. Common progress measures across institutions are being utilized to assess the extent to which completion grants prevent drop-out and facilitate completion among recipients.

Houston Guided Pathways to Success (GPS)

Comparatively low levels of degree completion and differences across demographic groups threaten the economic growth of the Houston region. However, rising post-secondary participation along with growing enrollment at Houston area community colleges and universities provide a tremendous opportunity to significantly increase degree attainment through collaborative strategic efforts. To facilitate such collaboration, the University of Houston is leading Houston GPS, which is a consortium of institutions, including other University of Houston System campuses (UH-Downtown and UH-Clear Lake) and the four major community college systems (Houston Community College System, Lone Star College System, San Jacinto College District, and Wharton County Junior College). Houston GPS aims to develop a plan to accelerate college completion in the greater Houston area. Collectively, these institutions serve over 200,000 students and are a reflection of the diverse city and region that they serve. Through Houston GPS, consortium institutions are implementing an integrated system of cohesive, interdependent strategies that include: (a) default pathways; (b) academic maps focused on 15 hours per semester; (c) meta-majors; (d) proactive advising; (e)workforce connections; (f)block scheduling; (g) co-requisite remediation; and (h) aligned mathematics. Collectively, these strategies intend to increase and accelerate student completion and smooth two-year to four-year college transfer, while improving educational quality for Houston area students. Collaboration across Houston GPS institutions and with national experts has resulted in strong commitment to a common completion agenda and progress measures.

\section{Applying the Model}

Individually and collectively, these programs exemplify the components (Kania \& Kramer, 2012) of collective impact outlined in Figure 1. In terms of a Common Agenda, improving college completion is an issue of national, state, and local concern and lies at the heart of each initiative. Low completion rates and the presence of attainment gaps are commonly understood problems, addressed collaboratively by removing barriers to success faced by students. Barrier identification is a focus of the Beyond Financial Aid initiative while other programs focus on overcoming specific completion challenges. For example, the Completion Grant Project focuses on providing funds for students with financial need to complete their degree within an academic

year while Houston Guided Pathways to Success provides students with streamlined pathways to reduce excess credits, decrease time to degree, and increase completion. 
These initiatives involve a number of collaborators including multiple institutions of higher education, national experts, and philanthropic organizations, all working toward a completion agenda. In doing so, collaborators in each initiative have agreed upon Common Progress Measures designed to assess the impact of strategies implemented. For example, Houston GPS institutions have set five-year targets for the following common set of outcomes to track the impact of Guided Pathways to Success strategies: (a) FTIC graduation rates; (b) transfer graduation rates; (c) time to degree; (d) credits to degree; (e) FTIC 1-year retention; (f) transfer 1-year persistence, (f) credit hour accumulation, and (g) completion of math and English gateway courses. Agreed upon progress measures for initiatives are reported at regular intervals supporting a culture of accountability.

Also facilitating accountability are Mutually Reinforcing Activities built into the structure of each initiative. Clear plans of action, which include specific roles and responsibilities that align with the common agenda, guide program activities. For example, Houston Guided Pathways to Success involves the development of comprehensive institutional implementation plans, with identified units and positions responsible for carrying out each component within a specified timeframe. Similarly, the Completion Grant Project involves specific roles for institutional constituents associated with identifying potential applicants, assessing eligibility criteria, and matching applicants with grant funds. In addition, mentors involved in this initiative play a key role in guiding the implementation of completion grant programs across institutions participating in the grant program.

Mentoring roles such as this also support the Communication component of collective impact, needed to ensure consistent and effective efforts toward the common agenda. Monthly mentoring calls occur as part of the Completion Grant Project. Regular communications, including phone calls, site visits, and conferences, take place with the OASIS and Houston GPS initiatives. Collaboration that occurs as a result of such routine communications has led to a number of insights that support and enhance the implementation of strategies to overcome completion barriers. As one example, working with content experts throughout the Houston GPS planning process has facilitated the implementation of proactive advising practices, and assisted with the transition from developmental courses to co-requisite remediation.

Collectively, a number of organizations provided critical human, fiscal, material and knowledge (technical expertise) resource support to help ensure success in attaining programmatic goals. For example, the Education Trust provided a strategic vision for the OASIS initiative, established a management and coordination team, facilitated communication with and between participating institutions, and created a process for institutional assessment and data collection. The Lumina Foundation provided critical financial support and technical assistance. The Association of Public and Land-grant Universities, the Coalition of Urban Serving Universities, and Complete College America have played key roles in establishing effective organizational structures for our initiatives.

\section{Conclusion}

As the University of Houston and other institutions of higher education continue on their path to address student attrition while increasing student retention and graduation rates, there is the 
promotion of a mindset that recognizes that we are all in this together: we are an ecosystem that consists of a set of people, communities and institutions that are interdependent. Collective impact as a practical guide and the ecology metaphor, as a conceptual underpinning, are serving as a road map for the democratic selection of programmatic tools and the development and implementation of said tools that will help us to bring about a healthy and productive educative system. This is the kind of system that will help to ensure that our educative institutions are coordinated, united, and successful in the critical goal to promote the success of all studentsparticularly low-income students in the quest toward college completion. 


\section{References}

Arum, R., \& LaFree, G. (2008, October). Educational attainment, teacher-student ratios, and the risk of adult incarceration among U.S. birth cohorts since 1910. Sociology of Education, 81, 397421. https://doi.org/10.1177/003804070808100404

Baum, S., Ma, J., \& Payea, K. (2013). Education Pays 2013: The Benefits of Higher Education for Individuals and Society. College Board: New York. Retrieved from https://trends.collegeboard.org/sites/default/files/education-pays-2013-full-report.pdf

Brofenbrenner, U. (1986). Ecology of the family as context for human development: Research perspectives. Developmental Psychology, 22(6), 723-742. https://doi.org/10.1037/0012$\underline{1649.22 .6 .723}$

Carnevale, A.P., Smith, N., \& Strohl, J. (2010). Help wanted: Projections of jobs and education requirements through 2018. Center on Education and the Workforce. Georgetown University. Retrieved from https://eric.ed.gov/?id=ED524310

Castagno, A.E., \& Brayboy, B.M.J. (2008). Culturally responsive schooling for indigenous youth: A review of the literature. Review of Educational Research, 78(4), 941-993. https://doi.org/10.3102/0034654308323036

Chaplot, P., Cooper, D., Johnstone, R., \& Karandieff, K. (2015). Beyond financial aid: How colleges can strengthen the financial stability of low-income students and improve student outcomes. Indianapolis: Lumina Foundation. Retrieved from https://www.luminafoundation.org/files/publications/BFA/Beyond.Financial.Aid.pdf

Coontz, S. (1992). The way we never were: American families and the nostalgia trap. Basic Books.

Dodge, T.M., Mitchell, M.F., \& Mensch, J.M. (2009). Student retention in athletic training education programs. Journal of Athletic Training, 44(2), 197-207. https://doi.org/10.4085/1062$\underline{6050-44.2 .197}$

Garcia, E., Jensen, B., \& Scribner, K. (2009). The demographic imperative. Educational Leadership, 66(7), 8-13. Retrieved from http://www.ascd.org/ASCD/pdf/journals/ed_lead/el200904_garcia.pdf

Gupton, J.T., \& Miksch, K. (2016). A theory of equity: A social and legal analysis of college access for low-income students. In P.A. Pasque, N. Ortega, J.C. Burkhardt, \& M.P. Ting (Eds.), Transforming understandings of diversity in higher education (pp. 44-53). Stylus Publishing: Sterling, Virginia.

Goodlad, J. (1984). A place called school. McGraw-Hill Co. 
Kania, J., \& Kramer, M. (2012). Channeling change: Making collective impact work. Stanford Social Innovation Review, Retrieved from: https://ssir.org/articles/entry/channeling_change _making_collective_impact_work

Kinder Institute. (2012). The 2012 Houston education survey: Public perceptions in a critical time. Rice University. Retrieved from https://kinder.rice.edu/uploadedFiles/Kinder_Institute_for_Urban_Research/SHEA/SHEA\%20E ducation\%20Report.pdf

McKinsey \& Company. (2009). The economic impact of the achievement gap in America's schools. Washington, D.C.: McKinsey \& Company. Retrieved from http://mckinseyonsociety.com/the-economic-impact-of-the-achievement-gap-in-americasschools/

National Center for Higher Education Management Systems. (2012). A new measure of educational success in Texas: Tracking the success of $8^{\text {th }}$ graders into and through college. Houston Endowment. Retrieved from http://www.txblc.org/wpcontent/uploads/2012/10/a_new_measure_of_educational_success_in_texas.pdf

Nelson, B. (2016). Biography. Retrieved from https://www.billnelson.senate.gov/about-bill

Ream, R.K., \& Rumberger, R.W. (2008). Student engagement, peer social capital, and school dropout among Mexican American and Non-Latino White students. Sociology of Education, 81(2), 109-139. https://doi.org/10.1177/003804070808100201

Schott Foundation. (2008). Given half a chance: The Schott Foundation 50 state report on public education and Black males. Cambridge, MA. Retrieved from

http://schottfoundation.org/report/given-half-chance-schott-50-state-report-public-education-andblack-males

Texas Higher Education Coordinating Board. (2015). 60X30 TX: Texas Higher Education Strategic Plan, 2015-2030. Texas Higher Education Coordinating Board. Retrieved from http://www.thecb.state.tx.us/reports/PDF/9306.PDF?CFID=68698548\&CFTOKEN=40613338

University of Houston Mission Statement. (2017). Retrieved from:

http://www.uh.edu/about/mission/

US News \& World Report. (2017). Campus Ethnic Diversity. Retrieved from: https://www.usnews.com/best-colleges/rankings/national-universities/campus-ethnic-diversity

Weaver-Hightower, M.B. (2008). An ecology metaphor for educational policy analysis: A call to complexity. Educational Researcher, 37(3), 153-167.

https://doi.org/10.3102/0013189X08318050 


\section{Author Information}

*Dr. Bruce Jones serves as the Vice Provost for Academic Programs at the University of Houston. He has over 25 years of academic and administrative experience in higher education, as well as extensive experience working with philanthropic institutions across the United States on program funding strategies, strategic planning and evaluation. His research foci includes educational leadership and policy analysis in K-12 and higher education, cross-sector collaboration, school and community interrelations and cultural competence and educational evaluation and assessment.

Bruce A. Jones

Office of the Provost

University of Houston

203 E Cullen Building

Houston, TX 77204-2019

Telephone: $713-743-2490$

Email: bajones4@uh.edu

Dr. Maureen Croft is the Associate Provost for Strategic Enrollment Planning at the University of Houston, where her principal responsibilities involve the development, implementation and management of undergraduate strategic enrollment planning. In this role, Dr. Croft leads efforts to develop strategic application, admission, enrollment and financial aid policies for undergraduates that serve to advance university enrollment and retention goals and reach targeted audiences.

Maureen G. Croft

Office of the Provost

University of Houston

203 E Cullen Building

Houston, TX 77204-2019

Telephone: 832-842-8703

Email: $\underline{\text { mgcroft@uh.edu }}$

Teri Elkins Longacre currently serves as Vice Provost and Dean for Undergraduate Student Success in the Office of Academic Affairs and is an Associate Professor of Management at the C. T. Bauer College of Business at the University of Houston. She teaches in the areas of business law, employment law, managerial communication, human resource management, and organizational behavior, and coordinates an internship program with the Equal Employment Opportunity Commission. Teri has published scholarly articles on the topics of employment discrimination, employee selection practices, affirmative action plans, leadership, and academic internship programs.

Teri E. Longacre

Office of the Provost

University of Houston

203 E Cullen Building

Houston, TX 77204-2019

Telephone: 832-842-8703

Email: elkins@uh.edu

*Corresponding author 